\title{
EFFECT OF IRRIGATION INTERVALS AND ROW DISTANCES ON YIELD AND ITS ATTRIBUTES OF FLAX (Linum usitatissimum L) UNDER CONDITIONERS AND SANDY SOIL.
}

El- Azzouni, A. M. A, and S. Z. A. Zedan

Fiber crops Res. Section, Field crops Res. Institute, Agriculture Research Center, Giza, Egypt.

\section{ABSTRACT}

The present investigation was conducted at Ismailia Agric. Res. Station Farm, Ismailia Governorate Egypt, during : 2004 / 05 and 2005 / 06 seasons, to study the influence of sprinkler irrigation intervals (1,2, 3 days), row distances (15 and 20 $\mathrm{cm}$ ) and Agar Agar as soil conditioner on the yield and yield components as well as their interaction on yield of new flax variety Giza 10 and its attributes. A split - split plot design with three replication was used. The results could be summarized as follows:

1- Irrigation intervals (I) had significant effect on plant height $\mathrm{cm}$, technical stem length, straw yield / plant, number of capsules / plant, seed yield /plant, seed yield fad, fiber yield / plant, fiber yield / fad, and straw yield fad ton in both seasons whereas technical stem length did not reach the level of significance in the first season. The highest values of this characters were obtained by three days as sprinkler irrigation intervals.

2 - Row distances (D) $20 \mathrm{~cm}$. produced the highest values of straw yield / plant, number of capsules / plant and seed yield / plant, while the highest plant height, technical stem length, seed yield / fad. , fiber yield / plant and per faddan and straw yield / fad were produced by row spacing $15 \mathrm{~cm}$. in both seasons.

3 - Agar Agar as soil conditioner (C) significantly affected all characters under study in both seasons compared with control.

4 - All interaction between the studied factors were not significant except IXC for plant height, technical stem length, number of capsules / plant, seed yield / plant, seed yield / fad, fiber yield / plant and fiber yield / fad. as well as DxC for plant height, fiber yield / fad and straw yield / fad Also IXD for number of capsules / plant, seed yield/plant, seed yield /fad and fiber yield /plant finally IxDxC for number of capsules /plant, fiber yield/ plant and per faddan.

It can be concluded that under sandy soil condition its recommended to cultivate flax crop and irrigated every three days for two hour time instead two and one days with $15 \mathrm{~cm}$ as row spacing under soil conditioner (Agar Agar) to availability water and increased nutrient in root zoon to obtained highest yield of straw and seed and its attributes

\section{INTRODUCTION}

Cultivate flax crop in reclamation sandy soil is feasible solution for the competition between flax and other winter crop (wheat and forage) which sowing in valley soil. Hence improve agriculture practice such as irrigation, distances between rows and enhancement soil structural by using soil conditioners to increased water holding capacity in sandy soil stile target for many investigators. Optimum irrigation regimes is a very important process. It 
studied by many researchers such as Pontoppidan ((1958), El - Farouk et al. (1982), El - kady (1985), El -Shimy et al. (1988), Miadenova (1998), El sabbagh et al. (1998), singh et al (2000), Moawed (2001), Al - Thabet (2003), Atta et al (2007) and Abo - kaied et al. (2007), they indicated that straw, seed yield of flax and most of its related character were increased by increasing number of irrigation or available soil moisture in root zone of plants.

The row spacing for flax plants also studied by many investigators. They reported that narrow row distances increased straw, fiber and seed yield / fad, Momtaz and Shalaby(1981), El-Farouk et al. (1982) Abd Alla et al (1989), Moawed (2001) AL kaddoussi and Moawed(2001), Zedan (2004) and Hussein et al (2007).

Agar Agar as soil conditioner which studied by many researchers like Wallace et al. (1986), Khadr et al. (1988), EL-Aggory Eglal et al. (2002) and Abo-Khaied et al. (2007) which found that a small amount of polyacrylamide (Agar Agar) or mycorrhizal inoculation would accomplish the same amount of aggregation that a large amount of organic mater can do. Applied at the concentration of $0.01 \mathrm{~kg} \mathrm{~m} 3(0.1 \%)$ in irrigation water during the entire season had an amendatory effect on infiltration.

Also increase water holding capacity, enhance nutrient efficiency and encourage soil micro flora in sandy soil (Azzam et al. 1987).

Therefore, the present investigation was carried out to study the effect of irrigation intervals, row spacing and Agar Agar as soil conditioners and their interaction on the yield and yield components of both straw and seed of flax productivity using the local Egyption variety Giza 10 during winter season of 2004 / 2005 and 2005 / 2006 at Ismailia Agric. Res. Station, Agricultural Research Center (A. R. C) Egypt.

\section{MATERIALS AND METHODS}

The present research work was conducted in sandy soil at Ismailia Agric. Res. Station, Ismailia Governorate, during 2004 /2005 and 2005 / 2006 winter seasons to investigate the effect of irrigation intervals, row spacing and using Agar Agar as soil conditioner and their interaction on yield of flax crop and its attributes.

Chemical and physical analysis of experimental soil is given in Table (1). New flax variety Giza 10 was used. Irrigation intervals were 1, 2, 3 days and the time of Irrigation period is two hour / interval under sprinkler irrigation system. Two row spacing through seeds $/ \mathrm{m}$ were investigated including $(20 \mathrm{~cm})$ between rows $\left(1500\right.$ seeds $\left./ \mathrm{m}^{2}\right)$ and $(15 \mathrm{~cm})$ between rows (2000 seeds $/ \mathrm{m}^{2}$ ). In this study Agar solution of $0.1 \%$ were sprayed under the growing plants after one month from sowing while the soil was still wet by the rate $1000 \mathrm{~L}$ / fad. foliar / fertilizer were used to all plots. One g. from Agar with 2. $5 \mathrm{~g} / \mathrm{L}$ from foliar $\mathrm{x}$, A control treatment was included and sprayed with water only. Foliar $x$ was locally produced by El Naser co. for pesticides and chemicals, Cairo. It contains $10 \% \mathrm{~N}, 7 \% \mathrm{P}, 8 \% \mathrm{k}, 2500 \mathrm{ppm}$ of each of chelated $\mathrm{Fe}, \mathrm{Zn}$ and 3000 ppm of chelated Mo in addition to tracs of Mg, S, B and $\mathrm{Cu}$. 
Table 1: Physical and chemical analysis of the soil before the sowing

\begin{tabular}{|cc|}
\hline \multicolumn{2}{|c|}{ 1- Mechanical analysis } \\
\hline Coarse sand (\%) & 68.52 \\
Fine sand (\%) & 35.71 \\
Silt (\%) & 3.5 \\
Clay (\%) & 2.41 \\
Textural class & Sandy \\
\hline \multicolumn{2}{|c|}{ 2- Chemical analysis: } \\
\hline PH & 7.63 \\
E.C (mm hos Cm-1 (1:5) & 0.099 \\
Organic Matter (\%) & 0.061 \\
Available N (ppm) & 7.13 \\
Available P (ppm) & 1.30 \\
Available K (ppm) & 49.80 \\
\hline
\end{tabular}

\section{Experimental design.}

A split - split plot design with three replication was used. Irriagation intervals were randomly distributed in main plots, while row spacing was randomly occupied the sub plots, sub - sub plots allocated by soil conditioner (Agar - Agar), plot area was $6 \mathrm{~m}^{2}(2 \times 3 \mathrm{~m})$. Seed were broadcaste on November $15^{\text {th }}$ and $20^{\text {th }}$ in $2004 / 2005$ and $2005 / 2006$ winter seasons, respectively. The preceding crop, was peanut in the two seasons Agricultural practices were applied as recommended for the region.

\section{Collected data}

A: Single plant observations :

At harvest time, ten quarried plants were taken at random from each sub - sub plot to measure the following characters:

1- Plant height $(\mathrm{cm})$, was measured from soil surface to the highest point of plant.

2-Technical stem length $(\mathrm{cm})$ was determined from soil surface to the first branches.

3 - Straw yield g./plant average yield of ten plants.

4 - Seed yield g./ plant average yield of ten plants.

5 - Number of capsules / plant.

6 - Fiber yield gm/plant was estimated as an average of fibers extracted from 10 plants.

B: Unite area observations:

7 -Straw yield ton/ fad was calculated from the whole plot area basis.

8 - Fiber yield $\mathrm{Kg} /$ fad was calculated from the whole plot area basis.

9 - Seed yield $\mathrm{Kg} / \mathrm{fad}$ was calculated from the whole plot area basis.

Statistical analysis:

The collected data were statistically analyses according to Sendecor and Cochran (1981). Differences among means were tested by using least significant difference test (L. S. D) at $5 \%$ level of significant. 


\section{RESULTS AND DISCUSSION}

Mean values of plant height, technical length and straw yield / plant for flax as affected by irrigation intervals, row spacing and Agar Agar as conditioner soil in the two successive seasons are presented in Table 2.

Analysis of variance showed significant differences in all studied characters for the three engine except with the average of technical stem length as affected by irrigation intervals in the first season, which did not reach the level of significance.

Table 2: Mean values of plant height $\mathrm{cm}$, technical stem length $\mathrm{cm}$ and straw yield plant $\mathrm{gm}$. as affected by irrigation intervals, row distances and soil conditioner in 2004 / 2005 and 2005 / 2006 seasons.

\begin{tabular}{|c|c|c|c|c|c|c|}
\hline \multirow{2}{*}{$\begin{array}{l}\text { Main effects } \\
\text { And interaction }\end{array}$} & \multicolumn{2}{|c|}{$\begin{array}{c}\text { Plant } \\
\text { height } \mathrm{cm}\end{array}$} & \multicolumn{2}{|c|}{$\begin{array}{c}\text { Technical stem length } \\
\text { cm }\end{array}$} & \multicolumn{2}{|c|}{$\begin{array}{c}\text { Straw } \\
\text { yield gm/plant }\end{array}$} \\
\hline & $2004 / 2005$ & $2005 / 2006$ & $2004 / 2005$ & $2005 / 2006$ & $2004 / 2005$ & $2005 / 2006$ \\
\hline \multicolumn{7}{|c|}{ I - Irrigation regimes (I) } \\
\hline One day & 61.21 & 58.22 & 49.89 & 41.61 & 1.14 & 1.05 \\
\hline Two days & 64.4 & 60.11 & 50.42 & 43.82 & 1.38 & 1.22 \\
\hline Three days & 65.07 & 62.52 & 51.83 & 47.75 & 2.32 & 2.14 \\
\hline F. Test & * & * & N.S & * & * & * \\
\hline L.S.D & 1.01 & 1.23 & N.S & 0.717 & 0.211 & 0.304 \\
\hline \multicolumn{7}{|c|}{ II - Row distances (D) } \\
\hline $\begin{array}{c}15 \mathrm{~cm} \text { between } \\
\text { rows }\end{array}$ & 66.71 & 63.19 & 54.07 & 48.58 & 2.31 & 1.37 \\
\hline $\begin{array}{c}20 \mathrm{~cm} \text { between } \\
\text { rows }\end{array}$ & 60.41 & 57.09 & 47.36 & 40.21 & 2.53 & 1.57 \\
\hline \multicolumn{7}{|c|}{ III - Soil conditioner (C) } \\
\hline Control & 59.91 & 58.00 & 51.21 & 47.21 & 2.37 & 1.40 \\
\hline Agar Agar & 67.21 & 62.58 & 50.22 & 41.58 & 2.47 & 1.54 \\
\hline \multicolumn{7}{|l|}{ IV - Interaction } \\
\hline IXD & N.S & N.S & N.S & N.S & N.S & N.S \\
\hline IXC & * & * & ${ }^{*}$ & * & N.S & N.S- \\
\hline DXC & * & * & N.S & N.S & N.S & N.S \\
\hline IXDXC & N.S & N.S & N.S & N.S & N.S & N.S \\
\hline
\end{tabular}

\section{1 - plant height $(\mathrm{cm})$ :}

Regarding plant height character, data revealed that three days as irrigation intervals ranked first with the mean values of 65.07 and $62.52 \mathrm{~cm}$, followed by two days which recorded $(64.4$ and $60.11 \mathrm{~cm})$ and the shortest plant height obtained by one day which recorded $(61.21$ and $58.22 \mathrm{~cm})$ in the first and second seasons, respectively. In this respect the shortest in plant height by increasing ones of irrigation intervals (one day) may be due to nutrient irrigate far from plants by ininfiltration which ability of sand soil to retention by nutrient is few Azzam et al (1987).

Opposite ranked were obtained under clay soil condition thus organic matter improvement soil structure, soil fertility and increases water- holding capacity by EL-Farouk et al (1982), EL-Shimy et al. (1988), Maowed (2001), Abo- Kaied et al (2007) and Atta et al (2007),. 
Results illustrated that the narrow distance between rows $(15 \mathrm{~cm})$ produced taller plants with the mean values of 66. 71 and 63. 19 than obtained by the wide space $(20 \mathrm{~cm})$ with mean values of 60.41 and $57.09 \mathrm{~cm}$ in both seasons, respectively. These results are in agreement with those obtained by Momtaz and Shalaby (1981), EL-Sweify et al. (1996), and Hussein et al (2007).

Agar Agar as soil conditioner affected significantly plant height. The tallest plant was obtained when adding Agar Agar 67. 21 and $62.58 \mathrm{~cm}$ in both seasons, respectively. Meanwhile, the shortest plant height was obtained under control (without Agar) 59. 91 and $58.00 \mathrm{~cm}$ in both seasons, respectively. This findings are in line with those of Wallace et al. (1986), Khadr et al. (1988), EL- Aggory Eglal et al. (2002), and Abo- Kaied et al. (2007)

The interaction between irrigation intervals and soil conditioners $(\mathrm{IxC})$ had significant effect on plant height in both seasons, but the interaction between irrigation intervals and row distances (IXD), row distances and soil conditioner (DxC) and (IxDXC) did not reach the level of significance in both seasons.

\section{2 - Technical stem length (cm) :}

Concerning technical stem length character, data obtained indicated similar trend with plant height behavior, by means that three days as irrigation intervals recorded highest technical stem length 51.83 and $47.75 \mathrm{~cm}$, followed by two days which recorded 50.42 and $43.82 \mathrm{~cm}$, while the shortest obtained by one day which mean values 49.89 and $41.61 \mathrm{~cm}$ in both seasons, respectively. opposite finding were obtained by many researchers under clay soil condition like El-kady (1985), Mladenova (1998), El- Sabbagh et al (1998), meanwhile Abo- Kaied et al (2007) confirm this finding.

The narrow rows distance $(15 \mathrm{~cm})$ encourage technical stem length with average 54. 07 and $48.58 \mathrm{~cm}$ when compared with the wide one (20 $\mathrm{cm}$ ) which recorded 47.36 and $40.21 \mathrm{~cm}$ in both seasons, respectively. These results similar with those obtained by El- Farouk et al. (1982), Abd Alla et al (1989) and Moawed (2001).

Concerning technical stem length character, data obtained similar trend with plant height by using Agar Agar as soil conditioner.

The interaction between $(\mathrm{IxC})$ had significant effect on technical stem length in both seasons. Meanwhile the interaction (IxD), (DxC) and (IxDxC did not reach the level of significance in both seasons.

\section{3 - Straw yield / plant :}

Regarding straw yield/plant, data revealed that three days as irrigation intervals reached maximum estimates with the mean values of 2.32 and $2.14 \mathrm{~g}$. followed by two days (1.38 and $1.22 \mathrm{~g}$.) and the lowest straw yield / plant obtained by one day which recorded 1.14 and $1.05 \mathrm{gm}$ in the first and second seasons, respectively. In this respect the increment of straw yield / plant due to three irrigation intervals may be due to increase nutrient in root zone because the infiltration is few. This finding are agreement with those obtained by Azzam et al. (1987), El- shimy et al. (1988) and El - 
Aggory Eglal et al. (2002). Results showed that the narrow distance between rows $(15 \mathrm{~cm})$ gave the lowest straw yield / plant with the mean values of 2. 31 and $1.37 \mathrm{gm}$, while the highest estimates values of 2.53 and $1.57 \mathrm{gm}$. in the first and second seasons, respectively. These results are in agreement with those obtained by Al Kaddoussi et al. (2001) and Zedan (2004).

Analysis of variance showed increased in this trait by using Agar Agar as soil conditioner, which highest straw yield plant 2.47 and $1.54 \mathrm{gm}$, while the control gave lowest 2.37 and $1.40 \mathrm{gm}$ in the first and second seasons, respectively.

The interaction between (IxD), (IxC), (DxC) and (IxD $x \mathrm{C})$ had insignificant effect on straw yield /plant $g$ in both seasons. Demonstrating that each studied factor act independently straw yield / plant.

Mean Values of number of capsules / plant, seed yield / plant and per fad. for flax plants as affected by irrigation intervals, row spacing and Agar Agar as soil conditioner in two successive seasons are presented in Table 3.

Analysis of variance showed significant differences in all studied factors for number of capsules / plant, seed yield / plant. and seed yield / fad. in the two successive seasons.

\section{4 - Number of capsules /plant :}

Irrigation intervals three days recorded the highest number of capsules / plant (4. 73 and 4. 13) followed by two days (3. 89 and 3. 41) while, the lowest obtained by one day (3. 28 and 3. 11) in both seasons, respectively.

Meanwhile the narrow distances between rows $(15 \mathrm{~cm})$ gave the lowest number of capsules with the values of $(3.76$ and 3 . 38) but the highest estimates obtained by wide space $(20 \mathrm{~cm})$ with the mean values of $(4.17$ and 3 . 72). in the first and second seasons, respectively. These results were in agreed those obtained by Moawed (2001) and Hussein et al (2007).

Soil conditioner (Agar Agar) affected significantly number of capsules / plant by height mean values of (4. 01 and 3. 62) while, control treat gave the lowest (3. 92 and 3. 48) in the first and second seasons, respectively. these results agreed with those found by Wallace et al (1986) and El - Aggory Eglal et al (2002).

The interaction between (IxD), (IxC) and (IxDxC) had significant effect number of capsules plant in the first and second seasons, respectively. Meanwhile, the interaction between (DxC) did not reach the level of significance in the first and second seasons. It mean that each studied factor acted separately.

\section{5 - seed yield gm /plant :}

Analysis of variance of seed yield / plant under various irrigation intervals showed significant effect Table 3.

Applying irrigation intervals three days for flax plant gave the heaviest seed yield / plant $(0.403$ and $0.393 \mathrm{~g})$ followed by two days $(0.391$ and 0 . 371 ) while, the lowest obtained by one day (0.383 and $0.352 \mathrm{~g})$ in both seasons, respectively. Opposite with results were obtained by Pontoppidan 
(1958), Singh et al (2000) and Atta et al (2007) under clay soil condition.

Results illustrated that the narrow distance between rows $(15 \mathrm{~cm})$ gave the lowest seed yield / plant $(0.386$ and $0.329 \mathrm{~g})$. Meanwhile, the highest seed yield / plant obtained by the wide space $(20 \mathrm{~cm})$ with the mean values of 0.398 and $0.415 \mathrm{~g}$ in both seasons, respectively. These results similar with those obtained by Abd Allah et al (1989) and El- Sweify et al (2007).

Table 3: Mean values of number of capsules / plant, seed yield / plant gm and seed yield / fad kg. as affected by irrigation intervals , row distances and soil conditioner in 2004 / 2005 and 2005 / 2006 seasons

\begin{tabular}{|c|c|c|c|c|c|c|}
\hline \multirow{2}{*}{\begin{tabular}{|c|} 
Main effects \\
and \\
interaction
\end{tabular}} & \multicolumn{2}{|c|}{$\begin{array}{c}\text { Number of capsules / } \\
\text { plants }\end{array}$} & \multicolumn{2}{|c|}{ Seed yield gm/ plant } & \multicolumn{2}{|c|}{ Seed yield $\mathrm{kg} / \mathrm{fad}$} \\
\hline & $2004 / 2005$ & $2005 / 2006$ & $2004 / 2005$ & $2005 / 2006$ & $2004 / 2005$ & $2005 / 2006$ \\
\hline \multicolumn{7}{|c|}{ I - Irrigation regimes } \\
\hline One day & 3.28 & 3.11 & 0.383 & 0.352 & 297.17 & 282.13 \\
\hline Two day & 3.89 & 3.41 & 0.391 & 0.371 & 301.59 & 291.41 \\
\hline Three day & 4.73 & 4.13 & 0.403 & 0.393 & 367.08 & 342.11 \\
\hline F.Test & * & * & * & * & * & * \\
\hline L.S.D & 0.311 & 0.792 & 0.010 & 0.021 & 8.96 & 12.17 \\
\hline \multicolumn{7}{|c|}{ II - Row distances } \\
\hline \begin{tabular}{|c|}
$15 \mathrm{~cm}$ \\
between rows
\end{tabular} & 3.76 & 3.38 & 0.386 & 0.329 & 341.94 & 335.21 \\
\hline $\begin{array}{c}20 \mathrm{~cm} \\
\text { between rows }\end{array}$ & 4.17 & 3.72 & 0.398 & 0.415 & 301.93 & 275.22 \\
\hline \multicolumn{7}{|c|}{ III - Soil conditioner } \\
\hline Control & 3.92 & 3.48 & 0.412 & 0.436 & 293.28 & 305.32 \\
\hline Agar Agar & 4.01 & 3.62 & 0.372 & 0.308 & 350.61 & 305.11 \\
\hline \multicolumn{7}{|l|}{ IV - Interaction } \\
\hline IXD & * & * & * & * & * & * \\
\hline IXC & * & * & * & * & * & * \\
\hline DXC & N.S & N.S & N.S & N.S & N.S & N.S \\
\hline IXDXC & * & * & N.S & N.S & N.S & N.S \\
\hline
\end{tabular}

Agar Agar as soil conditioners affected significantly seed yield / plant. The heaviest seed yield / plant was obtained when adding Agar Agar 0. 412 and $0.436 \mathrm{gm}$ in both seasons, respectively. Meanwhile, the lowest seed yield / plant was obtained under control treatment 0.372 and $0.308 \mathrm{~g}$ in both seasons, respectively. This findings are in line with those of Khadr et al (1988) and El-Aggory Eglal et al. (2002).

The interaction between (IXD) and (IXC) had significant effect on seed yield / plant in both seasons. On the other hand, the interaction between $(\mathrm{DxC})$ and $(\mathrm{I} \times \mathrm{DxC})$ did not reach the level of significance in both seasons.

\section{6- Seed yield $\mathrm{kg} / \mathrm{fad}$ :}

Seed yield / fad is the 2 second outcome of flax plant which cultivated in Egypt as double purpose. The obtained results herein showed significant variation in seed yield / fad for three factor under study i. e. irrigation intervals, row distances and soil conditioner. Table 3.

Irrigation intervals at three days gave the heaviest seed yield / fad 
367.08 and $342.11 \mathrm{~kg}$. followed by two days $(301.59$ and $291.42 \mathrm{~kg}$ ) while, the lowest obtained by one day as irrigation intervals (297. 17 and 282. 14) in both seasons, respectively. Opposite rank with results were obtained under clay soil condition by El-Sabbagh (1998), Moawed (2001),), meanwhile Abokaied et al (2007) confirm this finding.

Results reveled that the narrow distance between rows $(15 \mathrm{~cm})$ gave the highest seed yield / fad $\mathrm{kg}(341.94$ and $335.21 \mathrm{~kg})$. Meanwhile, the lowest seed yield /fad. obtained by the wide space $(20 \mathrm{~cm})$ with the mean values of 301.93 and $275.22(\mathrm{~kg})$. in both seasons, respectively. This results similar with those obtained by Momtaz and Shalaby(1981), Moawed (2001) and Hussein et al (2007).

Adding Agar Agar as soil conditioners gave the highest seed yield / fad 350. 61 and 305. $11 \mathrm{~kg}$. Meanwhile, the lowest seed yield / fad was obtained without soil conditioner 293. 28 and $305.32 \mathrm{~kg}$ in both seasons, respectively. Similar results were obtained by Wallace et al. (1986), Khader et al (1988), El- Aggory Eglal et al (2002) and Abo - kaied et al (2007)

The interaction between (IxD) and (IxC) had significant effect on seed yield / fad in both seasons. Meanwhile, the interaction between (DxC) and (IxDxC) did not reach the level of significance in both seasons. It could be recommended to irrigate flax every three days, row spacing $(15 \mathrm{~cm})$ and using Agar Agar as soil conditioner to obtained the highest seed yield / fad.

Mean values of fiber yield / plant $(\mathrm{g})$ and per fad $(\mathrm{kg})$ and straw yield / fad for flax plants as affected by irrigation intervals, row spacing and soil conditioner (Agar Agar) in the two successive seasons are present in Table (4).

Analysis of variance showed significant differences in all studied factors for fiber yield/plant, fiber yield / fad and straw yield / fad in the two successive seasons.

\section{Fiber yield $\mathrm{g} / \mathrm{plant}$ :}

Irrigation intervals (three days) gives the highest fiber yield / plant $(0$. 143 and $0.131 \mathrm{gm})$ followed by two days $(0.139$ and $0.120 \mathrm{~g})$ while, the lowest obtained by one day as irrigation intervals $(0.130$ and $.119 \mathrm{~g})$ in both seasons, respectively. Similar finding were obtained by Abo-kaied et al. (2007) and opposite under clay soil by El- shimy et al. (1988) and Atta et al. (2007).

The narrow rows distances $(15 \mathrm{~cm})$ gained the highest fiber yield / plant $(0.216$ and $0.139 \mathrm{gm})$ comparing with the wide rows distance $(20 \mathrm{~cm})$ (0.196 and $0.108 \mathrm{gm}$ ) in both seasons, respectively.

In respect with fiber yield / plant the results revealed that adding Agar Agar as soil conditioner gave the highest fiber yield / plant (0.209 and 0. 128 $\mathrm{gm})$ Meanwhile, the lowest obtained by control trait $(0.203$ and $0.119 \mathrm{gm})$ in both seasons, respectively. The interaction between (IXD), (IXC) and (IXDXC) had significant effect on fiber yield / plant in both seasons. Meanwhile, the interaction between (DxC) did not reach the level of significance in both seasons. 


\section{8- Fiber yield $\mathrm{Kg} /$ fad :}

Data of fiber yield / fad as affected by irrigation intervals, rows distances and soil conditioner are shown in Table 4. Irrigation intervals effect significantly in this character. Three day gives the highest fiber yield / fad (492. 05 and $416.17 \mathrm{~kg}$ ) and followed by two days (441. 46 and $391.42 \mathrm{~kg}$ ) while, the lowest obtained by one day as irrigation intervals in both seasons, respectively. It is a great interest to note that these is a appositive correlation between fiber yield / plant and fiber yield / fad. This is expected since yield is a resultants of productivity (fiber yield / plant). It mean that higher fiber yield / plant under specific irrigation intervals, rows spacing and soil conditioner gave also, higher fiber yield/ fad. These results are agree with those obtained by EL- Farouk et al.(1982) Moawed (2001).

Table 4: Mean values of fiber yield $\mathrm{g} /$ plant, fiber yield $\mathrm{kg} / \mathrm{fad}$ and straw yield ton/ fad as affected by irrigation intervals, row distances and soil conditioner in 2004 / 2005 and 2005 / 2006 seasons .

\begin{tabular}{|c|c|c|c|c|c|c|}
\hline \multirow{2}{*}{$\begin{array}{c}\text { Main effects and } \\
\text { interaction }\end{array}$} & \multicolumn{2}{|c|}{ Fiber yield gm/ plant } & \multicolumn{2}{|c|}{ Fiber yield kg/fad } & \multicolumn{2}{|c|}{ Straw yield ton/ fad } \\
\hline & $2004 / 2005$ & $2005 / 2006$ & $2004 / 2005$ & $2005 / 2006$ & $2004 / 2005$ & $2005 / 2006$ \\
\hline \multicolumn{7}{|c|}{ I- Irrigation regimes } \\
\hline One day & 0.130 & 0.119 & 401.12 & 355.16 & 2.673 & 2.313 \\
\hline Two day & 0.139 & 0.120 & 441.65 & 391.42 & 2.959 & 2.521 \\
\hline Three day & 0.143 & 0.131 & 492.05 & 416.17 & 3.280 & 2.898 \\
\hline F. Test & * & * & * & * & * & * \\
\hline L.S.D & 0.007 & 0.009 & 3.83 & 4.972 & 0.230 & 0.107 \\
\hline \multicolumn{7}{|l|}{ II - Row distances } \\
\hline $\begin{array}{c}15 \mathrm{~cm} \text { between } \\
\text { rows }\end{array}$ & 0.216 & 0.139 & 459.11 & 417.58 & 3.170 & 2.941 \\
\hline $\begin{array}{c}20 \mathrm{~cm} \text { between } \\
\text { rows }\end{array}$ & 0.196 & 0.108 & 430.58 & 357.59 & 2.770 & 2.214 \\
\hline \multicolumn{7}{|c|}{ III - Soil conditioner } \\
\hline Control & 0.203 & 0.119 & 422.57 & 347.56 & 2.880 & 2.303 \\
\hline Agar Agar & 0.209 & 0.128 & 467.18 & 427.61 & 3.060 & 2.852 \\
\hline \multicolumn{7}{|l|}{ IV - Interaction } \\
\hline IXD & * & * & N.S & N.S & N.S & N.S \\
\hline IXC & * & * & * & * & N.S & N.S \\
\hline DXC & N.S & N.S & * & * & * & * \\
\hline IXDXC & * & * & * & * & N.S & N.S \\
\hline
\end{tabular}

Similar finding were obtained by rows distances trait thus narrow distances $(15 \mathrm{~cm})$ gives higher fiber yield / fad by means (459. 11 and 417 . $58 \mathrm{~kg}$ ). While, the lowest fiber yield / fad obtained by the wide spacing (20 $\mathrm{cm})(430.58$ and $357.59 \mathrm{~kg})$ in both seasons, respectively

Agar Agar as soil conditioner gave the highest fiber yield / fad (467. 18 and 427. 61). Meanwhile, the lowest obtained by control treatment (422. 57 and 347. 56) in both seasons, respectively.

The interaction between (IXC), (DxC) and (IxDxC) had significant effect on fiber yield / fad in both seasons. Meanwhile, the interaction between (IxD) did not reach the level of significance in both seasons. It could be recommended to irrigate flax every three days, row spacing $15 \mathrm{~cm}$ and using Agar Agar as soil conditioners to obtained the highest fiber yield /fad. 


\section{9- Straw yield ton/ fad :}

Regarding straw yield ton/fad, data revealed that three days as irrigation intervals reached maximum estimates with the mean values of 3 . 280 and 2. 898 ton followed by two days(2. 959 and 2. 521 ton) and the lowest straw yield / fad obtained by one day which recorded (2. 673 and 2 . 313 ton) in the first and second seasons, respectively. The superiority of the third irrigation intervals may be due to suitable condition for increasing cell size and division like nutrients around plants in root zone which did not lost by arrigate water every day. These results are in agreement with those obtained by Azzam et al. (1987), EL-Aggory Eglal et al. (2002) and Abo-Kaied et al. (2007).

Narrow distance between rows $(15 \mathrm{~cm})$ gave the highest straw yield ton/ fad with the mean values of (3. 170 and 2. 941ton), while the lowest estimates obtained by the wide space $(20 \mathrm{~cm})$ with the mean values of $(2.770$ and 2. 214 ton) in both seasons, respectively. This results are in agreement with those obtained by Momtaz et al. (1981), El-Farouk et al. (1982) and Hussein et al (2007).

Soil conditioner Agar Agar gave the highest straw yield ton/ fad (3. 060 and 2. 852 ton). Meanwhile, the lowest obtained by control trait (2. 880 and 2. 303 ton) in the first and second season, respectively. similar results were obtained by Abo-Kaied et al. (2007).

The interaction between $(\mathrm{DxC})$ had significant effect on straw yield / fad ton in both seasons. Meanwhile, the interaction between (IXD), (IXC) and $(\operatorname{IxD} \mathrm{X})$ did not reach the level of significance in both seasons.

\section{REFERENCES}

Abd Alla, A. F, M. EL-Farouk, T. Nasr El-Din and S. Z. Zedan (1989). Variation in plant characteristics of tow flax varieties grown under different densities and nitrogen levels. Egypt. J. Appl. sci, 4(3) : 868878.

Abo-Kaied, H. M. H. Afaf E. A. , Zahana and T. A. Abo-Zaied (2007) Effect of mycorhizal inoculation on yield and drought tolerance of some flax varieties - J. Agric. Sci. Mansoura Univ. 32 (4) : 2421-2431.

AL-Kaddoussi, A. R. and E. A. Moawed(2001). Yield analysis of seed and straw yield components under three row spacing for some genotypes of flax (Linum usitatissimum L. ) Egypt. J. Apple. Sci, 16(12):426-441.

AL-Thabet, I. S. S. 2003. Effect of irrigation interval on growth and yield of three flax varieties. Egypt. J. Apple. Sci. , 18 (3B):538-548.

Atta, Y. I. M. , M. M. M. Hussein and A. A. Nasser(2007) Some factors affecting linseed (Linum usitatissimum L. ) yield, quality and water use efficiency. Zagazig. J. Agric. Res. , 34 (4): 617-642.

Azzam, R, R. Ayoub, M. Khallafallah, and H, Moawed. (1987). Field application of polymeric gel, RAPG in desert plantation - Third international conf. On Radiation. Processing for plastic and rubber, 
Lodbroke Hotel, Warwick, UK Nov. 2-4 UK.

EL-Aggory Aglal M. , SH. M. Abd- EL- Rasoul and R. I. Kanany(2002). The biopolymer, AGAR AGAR, as a soil conditioner. Egypt. J. Agric. Res. , 80 (1): 13-27.

El-Farouk, M. , E. A. Mahmoud, A. L. Sahsah and H. M. Eid(1982). Water stress and plant density in relation to yield and some technological properties of flax fiber, Res. Bull. 470 Fac. of Agric Zagazig univ.

EL-Kady, E. A. F. 1985. Effect of water and fertilizer requirements on quantitive and qualitative characters of flax, Ph. D. Thesis Fac, of Agric, Kafer El-Sheikh, Tanta Univ.

El-Sabbagh, A. A. , S. A. Abd El-Hafez and El-Sh. I. Abo-Ahmed 1998. Response of some flax cultivars to water stress. Menofiya J. Agric Res. , Vol. 23(5) : 1367-1376.

El-Shimy, G. H. , M. El-Farouk, N. G. Ainer and A. I. Sahsah (1988). Effect of irrigation regimes and nitrogen fertilization on yield, yield components and anatomical characters of flax. Agric. Res. Rev. Cairo, 65(15):1-22.

El-Sweify, A. H. H, and S. H. A. Abd Le-Dayem and Amaney, M. M. El-Refaie 2007. Effect of plant density and potassium fertilizer on yield and its quality of some flax genotypes under sandy soil conditions. J. Agric. Sci. Mansoura univ. , 32(1):99-115

Hussein, M. M. M;M. A. Abdel -Dayem and Amaney, M. M. EL -Refie 2007. Effect of plant density and potassium fertilizer on yield and its quality of some flax genotypes under sandy soil conditions. J. Agri. Sinc. Mansoura Univ. , 32(1):99-115.

Khadr, M. S. ;A. H. Abd El-Hady ; Y. H. Mohamed and M. O. El-Moatasem. 1988. Effect of some soil amendments on the productivity of a sandy and calcareous alkaline soil. Inter. symp. soil conditioners. National Res. Center, Cairo, Egypt pp 197-204.

Mladenova, B. 1998. Necessity of irrigation and its influence on flax seed yield under the conditions of the high fields in western. Bulgaria Rasteniev " dni - Nauki, 35(1) : 26-29

Moawed, E. A 2001. Effect of microelements and row distances on the yield of some flax (Linum usitatissimumn L. ) varieties. Egypt, J. Appl, Sci, 16(6) : 157-172

Momtaz, A ; and T. A. shalaby 1981. studies of plant density and nitrogen fertilizer levels effect on yield and quality of flax. J. Agric. Res. Tanta Univ. 7(1):211-222.

Pontoppidan, H. 1958. Traits with watering of fiber flax-lin 12 (3): 21-32 (c. f. Field Crop Abst. , 11 1686).

Singh - Sp; R. S Dixit and G. R Singh 2000. Response of linseed to various moisture regimes and nitrogen levels on moisture depletion pattern, consumptive use and water use efficiency. Environment and Ecology, 18(I):37-38.

Snedecor, G. W and W. G Cochran 1980. Statistical Method. $7^{\text {th }}$ Ed, lowa State Univ. , press Ames. , lowa, U. S. A. : $325-330$.

Wallace, A.; G. A. Wallace and A. M. Abu -Zamzam. 1986. Effects of soil conditioners on water relationships in soils. Soil Sci. , 141: 346-351. 
Zedan, S. A. 2004 Response of some flax varieties to planting methods and plant densities. Egypt. J. Appl. Sci. , 19(9A) : $108-121$.

\section{تأثير فترات الري ومسـافات الزراعة على محصول الكتان ومكوناته تحت ظروف محسنات التربة والأرض الرئ الرملية

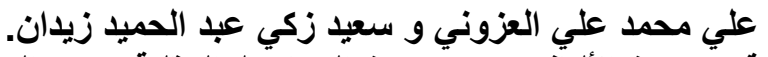

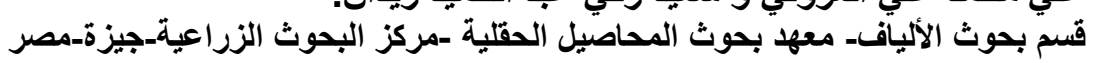

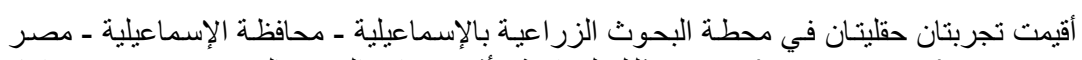

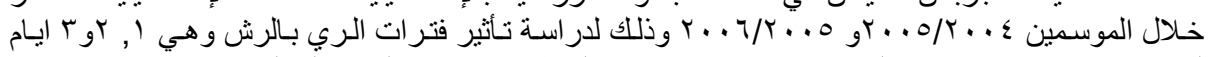

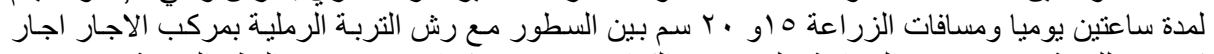

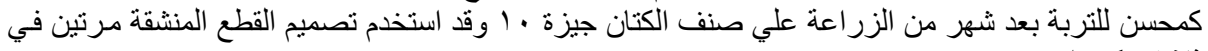

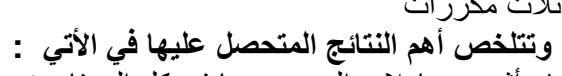

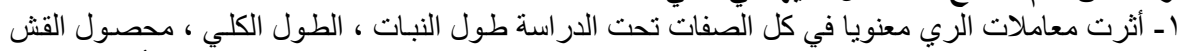

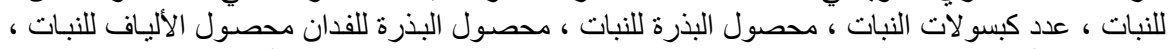

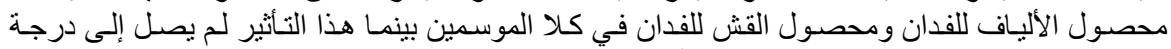

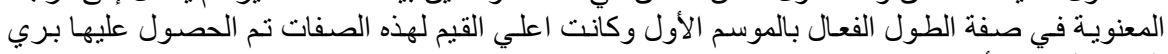
الكتان كل ثثلاثة أيام.

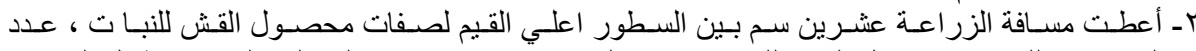

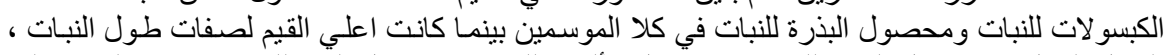

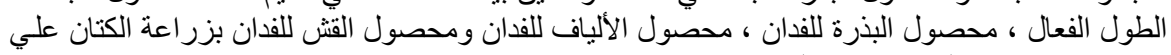

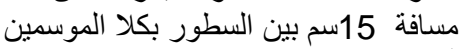

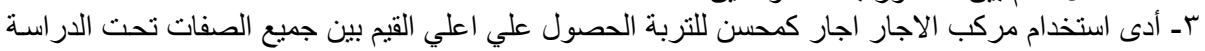

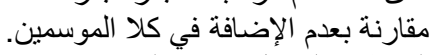

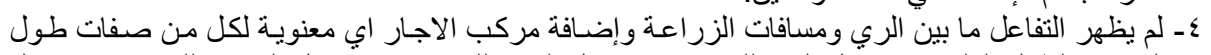

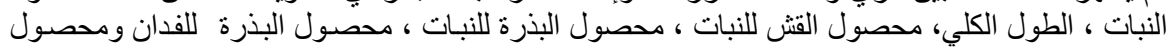

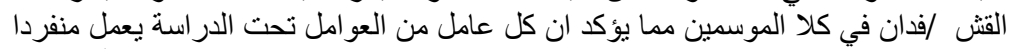

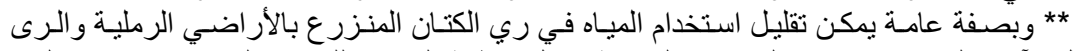

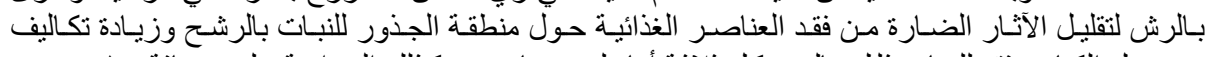

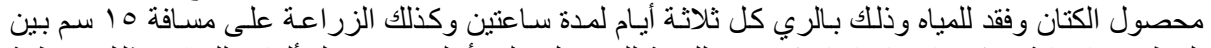

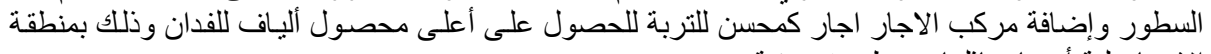

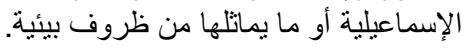

